\title{
Planning Production Capacity Using Time Series Forecasting Method and Linier Programming
}

\author{
M. Tirtana Siregar ${ }^{1}$, S. Pandiangan ${ }^{1} \&$ Dian Anwar ${ }^{1}$ \\ ${ }^{1}$ Program study of Management logistic for Electronics Industry, Polytechnic APP Jakarta, Ministry of Industry, \\ Indonesia \\ Correspondence: M. Tirtana Siregar, Program study of Management logistic for Electronics Industry, \\ Polytechnic APP Jakarta, Ministry of Industry, Indonesia. E-mail: tirtana.mts@gmail.com
}

Received: May 3, 2018

doi:10.5539/emr.v7n2p20
Accepted: September 28, 2018 Online Published: October 1, 2018

URL: http://doi.org/10.5539/emr.v7n2p20

\begin{abstract}
The objectives of this research is to determine the amount of production planning capacity sow talc products in the future utilizing previous data from january to december in year 2017. This researched considered three forecasting method, there are Weight Moving Average (WMA), Moving Average (MA), and Exponential Smoothing (ES). After calculating the methods, then measuring the error value using a control chart of 3 (three) of these methods. After find the best forecasting method, then do linear programming method to obtain the exact amount of production in further. Based on the data calculated, the method of Average Moving has a size of error value of Mean Absolute Percentage Error of 0.09 or 9\%, Weight Moving Average has a size error of Mean Absolute Percentage Error of 0.09 or 9\% and with Exponential Method Smoothing has an error value of Mean Absolute Percentage Error of 0.12 or 12\%. Moving Average and Weight Moving Average have the same MAPE amount but Weight Moving Average has the smallest amount Mean Absolute Deviation compared to other method which is $262.497 \mathrm{~kg}$. Based on the result, The Weight Moving Average method is the best method as reference for utilizing in demand forecasting next year, because it has the smallest error size and has a Tracking Signal not exceed the maximum or minimum control limit is $\leq 4$. Moreover, after obtained Weight Moving Average method is the best method, then is determine value of planning production capacity in next year using linier programming method. Based on the linier programming calculation, the maximum amount of production in next year by considering the forecasting of raw materials, production volume, material composition, and production time obtained in one (1) working day is $11,217,379 \mathrm{pcs} /$ year, or 934,781 pcs / month of finished product. This paper recommends the company to evaluate the demand forecasting in order to achieve higher business growth.
\end{abstract}

Keywords: forecasting, raw material, linier programming

\section{Introduction}

\subsection{Introduce the Problem}

Demand planning in general is known forecasting. Forecasting is an objective calculation using the data in the past, to specify something in the future. The necessary forecasting that must done by the company is product demand from customer requirements. By find out forecasting of production planning it can assist the company in determining the amount of product that should be in production. Therefore, with the forecasting, the company can achieve the goals and decision-making in determining the production capacity. However, in forecasting activities required the implementation of methods, it aims to minimize forecasting errors.

TEMPO Group is one of the Indonesian companies that engaged in an FMCG (Food Manufacturing Consumer Goods) and one of the business in this company is producing the powder for babies which need raw materials is talc. The company undertook its production demand planning still using conventionally method only on demand request, does not have a methods of Production Planning and Inventory Control, therefore, there is no effective method in order to calculate production planning forecasting.

Previous research states that only the implementation of forecasting methods, without calculating the planned production capacity. Therefore, the forecasting technique by calculating the maximum planning of production capacity is also intended to solve the problems that occur and perform an accurate production planning in 
response to customer demand in order to achieve effective and efficient value.

\subsection{Explore Importance of the Problem}

The results obtained advantage and contribute for learning development of science PPIC (Production Planning Inventory Control) and the company can be used as an input in activities of production planning. Moreover, production planning and control activities can be able controlled and can reduce wastage as well as maintaining consumer satisfaction.

Nasution and Prasetiawan (2008) described Demand forecast is the level of demand for products that are expected to be realized for a certain period of time in the future. Forecasting this request will be a very important input in the company's planning and control decisions.

\subsection{Relevant Scholarship}

Margaretha (2015) in their paper describes using time series forecasting techniques seems to be a good strategy if demand is highly volatile or resources are scarce.

Cheng, Akkarapol, Beyca, Le,Hui Yang, Zhenyu (2015) Time series forecasting has become essential toward advancing the way we manage and control complex real-world systems-from a conventional detectiondiagnosis-mitigation to a more proactive prediction- prognosis-prevention paradigm.

\subsection{State Hypotheses and Correspondence to Research Design}

The forecasting method is based on the use of variable relationship pattern analysis to be estimated with the time variable, which is the time series. Here are some of the Time Series methods used to find Forecast Demand (Demand Forecasting), such as:

\section{1). Moving Average (MA)}

(Moving Average) is a method of forecasting that is act by taking a group of observation values, find out the average value as a forecast for the period in further. Single Moving Average method has special characteristics that is :

a. To determine the forecast in the future period requires historical data over a period of time. For example, with a 3 month moving average, the 5th month forecast is only made after the 4th month finishes / ends. If the month of the 7 th month moving average can only be made after the 6th month ends.

b. Increasingly time period of moving average, the slicking effect is more visible in the forecast or resulting in a smoother moving average

\section{2). Weight Moving Average (WMA)}

Weighted Moving Avarage Method is the same simple moving average calculation method, but it needs a coefficient of weighing and is used if there is a trend in the past pattern. Included in the quantitative method is the econometric model, the input-output analysis model and the regression model. The weighted moving average model is more responsive to change, since data from the new period is usually given greater weight. View the historical pattern of the actual data of the request, in the event of a substantial change or unstable movement during that time period. Use a weighted moving average forecasting model

\section{3). Exponential Smoothing (ES)}

Exponential Smoothing method is the procedure of continuous improvement for forecasting for the latest observation object. This forecasting method emphasizes the exponentially decreasing priority of older observational objects. On the exponential smoothing there is one or more of the specified explicity smoothing parameter, and these results determine the weight imposed on the value of observation.

\section{Method}

The process of making this research through several stages which are interrelated and support each other. Starting with the preliminary studies by studying the previous studies used as a reference for determining the title to be appointed. After the title was set, next step is the creation of constraints and formulate the issues that will be discussed. After that, the creation of constraints and formulate the problem is identify to the need for data to be used and needed, which correspond to the theme and title and can meet the answers to the existing problems. In collecting data done by interview and literature study, interview conducted to the main person who in charge in production department.

\subsection{Research Method}

This research is included in quantitative research, which is about research that is calculating and systematic. In 
the process of quantitative research is a lot of doing calculations done systematically, well planned and structured. In the writing of this research, research methods conducted by determining the appropriate forecasting methods and can be applied in the company and also make the forescasting prediction in further. how to use the data processing as follows:

1). Tabulation

This technique arranges data in the form of tables or diagrams. In this research the table is used for forecasting process, error value and control chart

2). Data Analysis

As to be obtained in processing the data are:

a. Calculates demand forecasting using Moving Average, Weight Moving Average and Exponential Smoothing methods.

b. Comparing the results of forecasting obtained by using the error value and map control.

c. Calculate production planning using linear simplex programming.

\section{Results}

\subsection{Data Actual}

Forecasting is an important thing that must be conducted by the company in order to plan the needs of raw materials, therefore, it required to choice an appropriate forecasting methods in order the forecasting value results not big different from the reality. The demand data of talc powder raw material in year 2017 is shown in Figure 1 below.

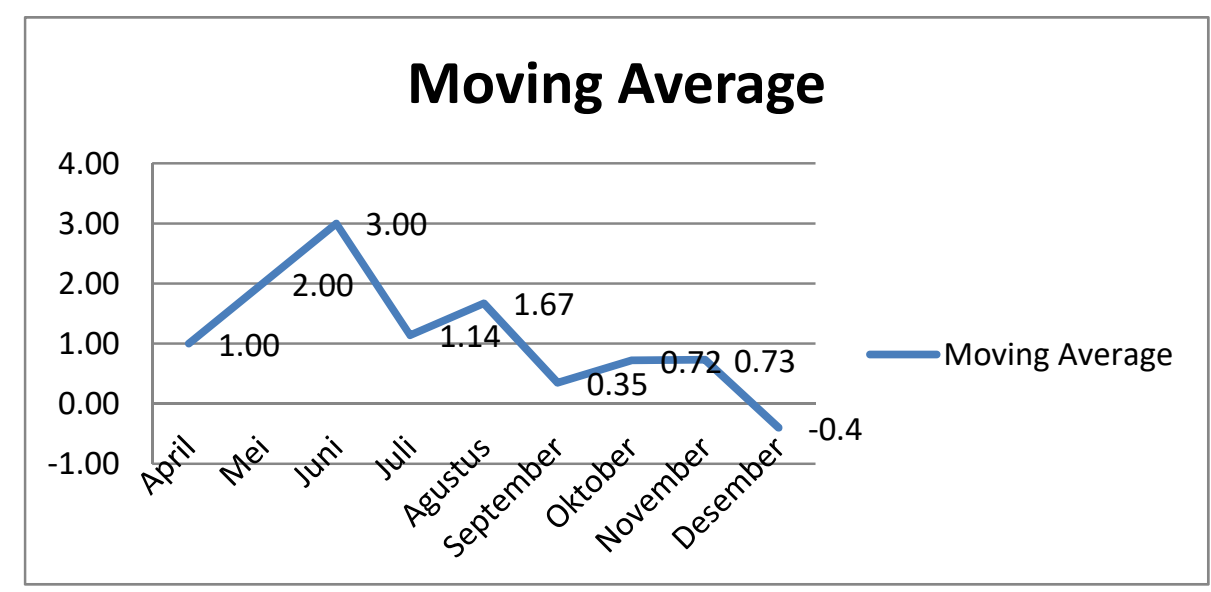

Figure 1. Graphic actual demand in 2017

\subsection{Forecasting Method Calculation}

In making this research the author uses the method of Time Series which include: Moving Average method, Weight Moving Average, and Exponential Smoothing. Then the calculation will be conducted as follows :

1). Moving Average (MA) method

Moving Average method is a method of forecasting where the number of data requests in the previous period is divided by the number of data in that period.

$$
\mathrm{D}^{\prime} \mathrm{t}=\frac{\mathrm{Dt}-1+\mathrm{Dt}-2+\ldots+\mathrm{Dt}-\mathrm{m}}{\mathrm{N}}
$$

Notes:

$\mathrm{n}=$ number of time series used

$D^{\prime} \mathrm{t}=$ forecasting for the coming period

$\mathrm{Dt}=$ demand actual in period $\mathrm{t}$ 
Dt-m $=$ Data for next period

the moving average is selected 3 (three) months because the demand changes significantly over time, then the forecast should be aggressive, so a small $\mathrm{N}$ value is more suitable. Here is the calculation with data of powder powder demand in 2017, with shown in Figure 2.

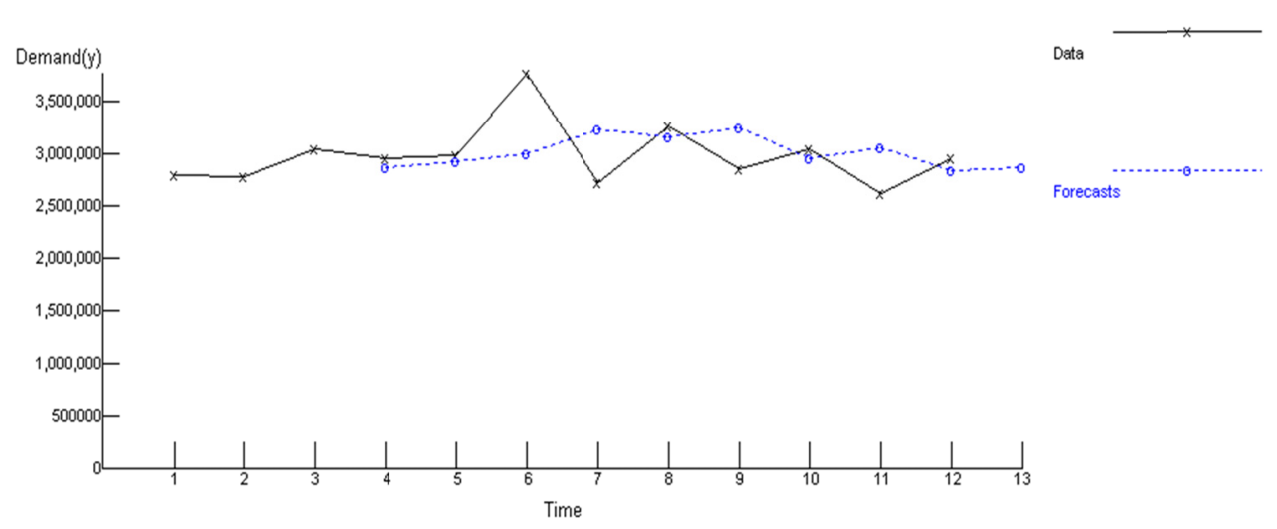

Figure 2. Graphic moving average

After the calculation of forecasting, next will be calculated error rate. The required data is the value of forecasting errors (e) and the squared error values $\left(\mathrm{e}^{2}\right)$ will be able to simplify the calculation of error rates by MAD, MSE and MAPE methods. The formula for finding the value of forecasting errors (e) and the squared error values $\left(\mathrm{e}^{2}\right)$ is by reducing the actual query data to the forecast value according to the period.

Table 1. Tracking signal using moving average method

\begin{tabular}{|c|c|c|c|c|c|c|c|c|c|}
\hline $\begin{array}{l}\text { Period } \\
\mathrm{N} \\
(1)\end{array}$ & $\begin{array}{l}\text { Demand } \\
\text { D } \\
(2)\end{array}$ & $\begin{array}{l}\text { Forecast } \\
\text { D't } \\
\text { (3) }\end{array}$ & $\begin{array}{l}\text { Error } \\
\text { E } \\
\text { D-D't } \\
(4)\end{array}$ & $\begin{array}{l}\text { RSFE } \\
\text { (5) } \\
\text { Cumulative } \\
\text { (4) }\end{array}$ & $=$ & $\begin{array}{l}\text { Absolute } \\
\text { Error } \\
(6) \\
\text { Absolute } \\
\text { (4) }\end{array}$ & $\begin{array}{l}\text { Cumulative } \\
\text { Absolute Error } \\
\text { (7) = Cumulaitve } \\
\text { (6) }\end{array}$ & $\begin{array}{l}\text { Cumulative } \\
\text { MAD } \\
(8)=(7) /(1)\end{array}$ & $\begin{array}{l}\text { Tracking } \\
\text { Signal } \\
(9)= \\
(5) /(8)\end{array}$ \\
\hline
\end{tabular}

\begin{tabular}{lllllllll}
\hline Jan & 2791625 & & & & & & \\
Feb & 2772230 & & & & & & \\
Mar & 3045500 & & & & & & & \\
Apr & 2953190 & 2869785 & 83405 & 83405 & 83405 & 83405 & 83405 & 1.00 \\
May & 2990440 & 2923640 & 66800 & 150205 & 66800 & 150205 & 75102.50 & 2.00 \\
Jun & 3759400 & 2996376.7 & 763023 & 913228 & 763023 & 913228.33 & 304409.44 & 3.00 \\
Jul & 2726785 & 3234343.3 & -507558 & 405670 & 507558 & 1420786.67 & 355196.67 & 1.14 \\
Agu & 3262080 & 3158875 & 103205 & 508875 & 103205 & 1523991.67 & 304798.33 & 1.67 \\
Sep & 2851375 & 3249421.7 & -398047 & 110828 & 398047 & 1922038.33 & 320339.72 & 0.35 \\
Oct & 3044645 & 2946746.7 & 97898 & 208727 & 97898 & 2019936.67 & 288562.38 & 0.72 \\
Nov & 2620725 & 3052700.0 & -431975 & -223248 & 431975 & 2451911.67 & 306488.96 & -0.73 \\
Dec & 2948390 & 2838915.0 & 109475 & -113773 & -113773 & 2561386.67 & 284598.52 & -0.40 \\
\hline
\end{tabular}

After the calculation in the control chart, the Tracking Signal can be seen from the Moving Average Method graph, the result of this method does not exceed the maximum limit of $\leq 4$. The highest Tracking Signal is in June that touches 3.00 is still within the maximum limit, but will still be compared with other methods. 


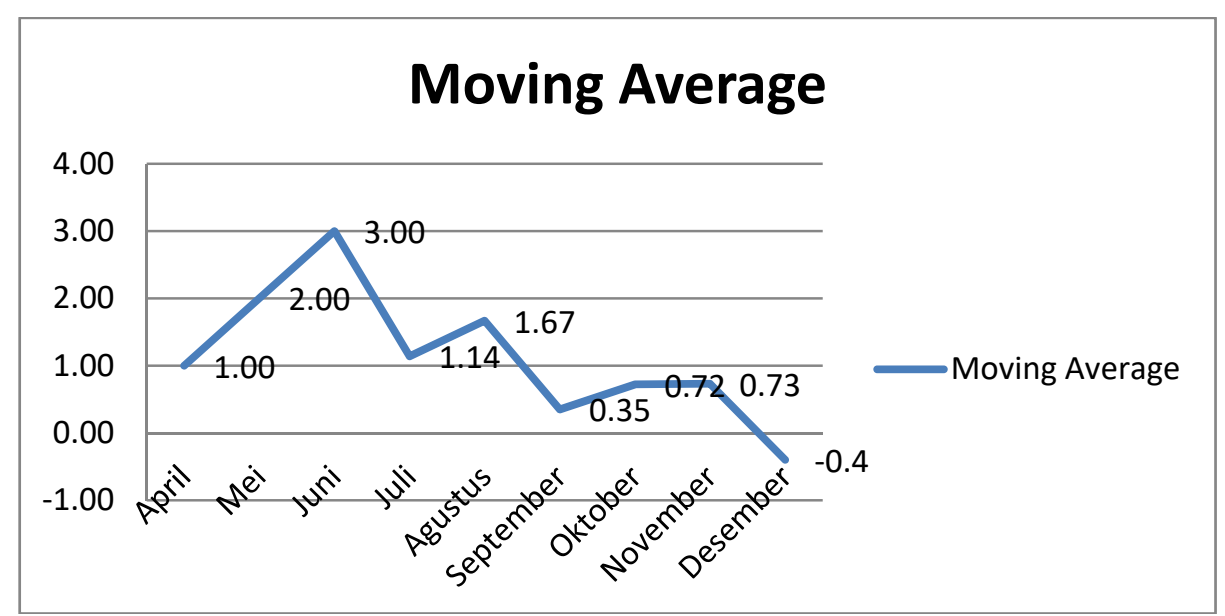

Figure 3. Tracking signal moving average method

\section{2). Weight Moving Average (MA) Method}

Weight Moving Average Model is more responsive to change, because the new data from the period is usually given more weight. A moving average model n-period weighted (Weighted Moving Average), stated the following:

$$
D^{\prime} t=(w 1 . D t-1)+(w 2 . D t-2)+(w n \cdot D t-n)
$$

Notes:

$D^{\prime} t=$ forecasting for the coming period

$\mathrm{Dt}=$ Demand actual in period $\mathrm{t}$

$\mathrm{w} 1=$ weights given in the period $\mathrm{t}-1$

$\mathrm{w} 2=$ weights given in the period $\mathrm{t}-2$

$\mathrm{w} 3=$ weights given in the period $\mathrm{t}-\mathrm{n}$

$\mathrm{n}=$ period

Giving weight to the model weight moving average of 3 (three) monthly weighted, with following:

Table 2. Weight coefficient of weight moving average

\begin{tabular}{ll}
\hline Period (month) & Coefficient \\
\hline 1 month ago & 0.4 \\
2 months ago & 0.4 \\
3 months ago & 0.2 \\
Total & 1 \\
\hline
\end{tabular}

Calculation result of forecasting with the actual data of demand can be seen using the graphic in the next page : 
Weight Moving Average

Method Weighted Moving Averaçes - \# Periods to average:

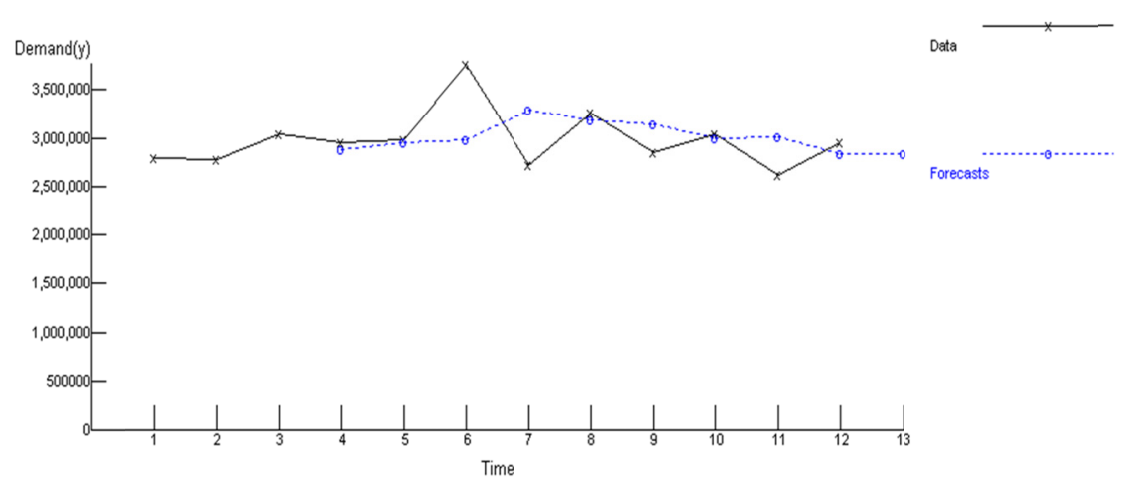

Figure 4. Graphic weight moving average

Tracking signal of forecasting errors (e) and the squared error values $\left(\mathrm{e}^{2}\right)$ with calculation of error rates by MAD, MSE and MAPE methods as shown in table below :

Table 3. Tracking signal using weight moving average method

\begin{tabular}{|c|c|c|c|c|c|c|c|c|}
\hline $\begin{array}{l}\text { Period } \\
\text { N } \\
(1)\end{array}$ & $\begin{array}{l}\text { Demand } \\
\text { D } \\
\text { (2) }\end{array}$ & $\begin{array}{l}\text { Forecast } \\
D^{\prime} \text { 't } \\
\text { (3) }\end{array}$ & $\begin{array}{l}\text { Error } \\
\text { E }= \\
\text { D-D't } \\
\text { (4) }\end{array}$ & $\begin{array}{l}\text { RSFE } \\
\text { (5) } \\
\text { Cumulative } \\
\text { (4) }\end{array}$ & $\begin{array}{l}\text { Absolute } \\
\text { Error } \\
\text { (6) } \\
\text { Absolute } \\
\text { (4) }\end{array}$ & $\begin{array}{l}\text { Cumulative } \\
\text { Absolute Error } \\
\text { (7) = } \\
\text { Cumulaitve (6) }\end{array}$ & $\begin{array}{l}\text { Cumulative } \\
\text { MAD } \\
(8)=(7) /(1)\end{array}$ & $\begin{array}{l}\text { Tracking } \\
\text { Signal } \\
(9) \\
(5) /(8)\end{array}$ \\
\hline Jan & 2791625 & & & & & & & \\
\hline Feb & 2772230 & & & & & & & \\
\hline Mar & 3045500 & & & & & & & \\
\hline Apr & 2953190 & 2885417 & 67773 & 67773 & 67773 & 67773 & 67773 & 1.00 \\
\hline May & 2990440 & 2953922 & 36518 & 104291 & 36518 & 104291 & 52145.5 & 2.00 \\
\hline Jun & 3759400 & 2986552 & 772848 & 877139 & 772848 & 877139 & 292379.7 & 3.00 \\
\hline Jul & 2726785 & 3290574 & -563789 & 313350 & 563789 & 1440928 & 360232.0 & 0.87 \\
\hline Agu & 3262080 & 3192562 & 69518 & 382868 & 69518 & 1510446 & 302089.2 & 1.27 \\
\hline Sep & 2851375 & 3147426 & -296051 & 86817 & 296051 & 1806497 & 301082.8 & 0.29 \\
\hline Oct & 3044645 & 2990739 & 53906 & 140723 & 53906 & 1860403 & 265771.9 & 0.53 \\
\hline Nov & 2620725 & 3010824 & -390099 & -249376 & 390099 & 2250502 & 281312.8 & -0.89 \\
\hline Dec & 2948390 & 2836423 & 111967 & -137409 & 111967 & 2362469 & 262496.6 & -0.52 \\
\hline
\end{tabular}

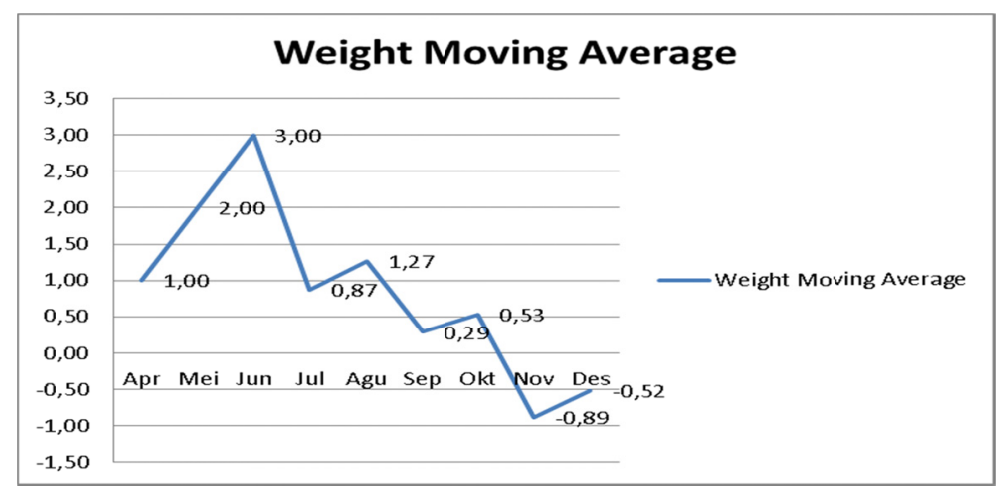

Figure 5. Tracking signal weight moving average method 
After the calculation of the control chart can be seen in graph of Weight Moving Average Method, the result of this method is not exceeding the maximum limit of $\leq 4$. The highest Tracking Signal is in June that touches amount 3.00 is still within the maximum limit, but will be compared with other methods.

\section{3). Exponential Smoothing (ES) Method}

Exponential Smoothing is a repeating calculation constantly which uses the latest data. Each data is weighted, where the weights are used with $\alpha$. The $\alpha$ symbol can be determined freely, which reduces the forecast error. In this calculation using the weights of 0.99 due to the significant fluctuations weights used approaches a value of 1 , so it will approach a more accurate value. The value of constant $\alpha$ can be selected between 0 and as it is: $0<\alpha<1$. Mathematically, the equation of exponential writing in below:

$$
D ’ t+1=\alpha \cdot D t+(1-\alpha) \cdot D^{\prime} t
$$

Notes:

D't $+1=$ value of forecasting for next period

A $=$ constanta $(0-1)$

$\mathrm{D}=$ data in period $\mathrm{t}$

$D^{\prime} t=$ average smoothed to period $t-1$

Demand forecasting calculations using Exponential Smoothing, the graph is shown below :

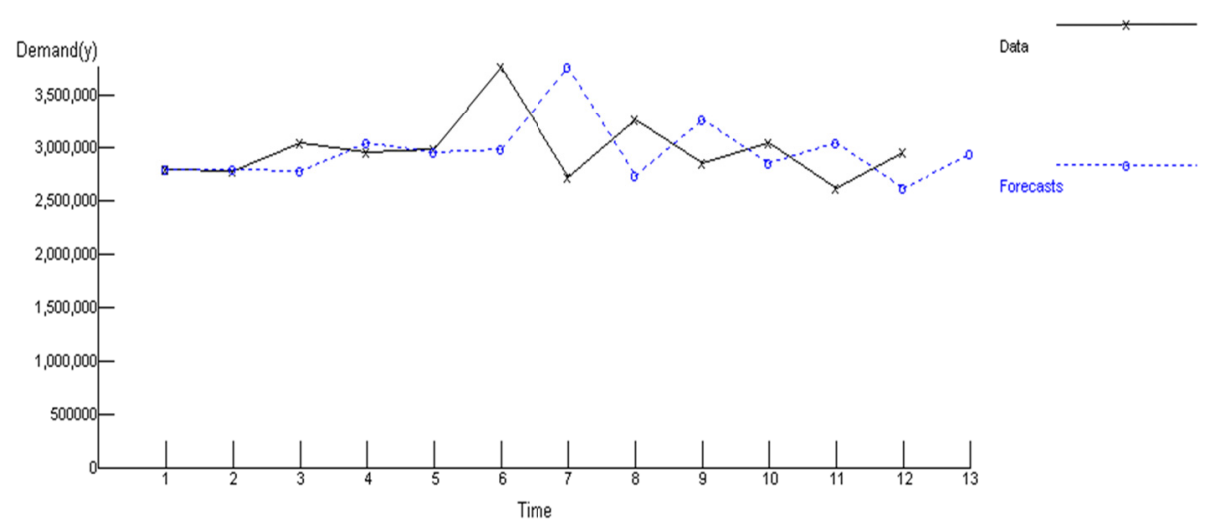

Figure 6. Graphic exponential smoothing (ES)

Tracking signal of forecasting errors (e) and the squared error values $\left(\mathrm{e}^{2}\right)$ with calculation of error rates by MAD, MSE and MAPE methods as shown in table below :

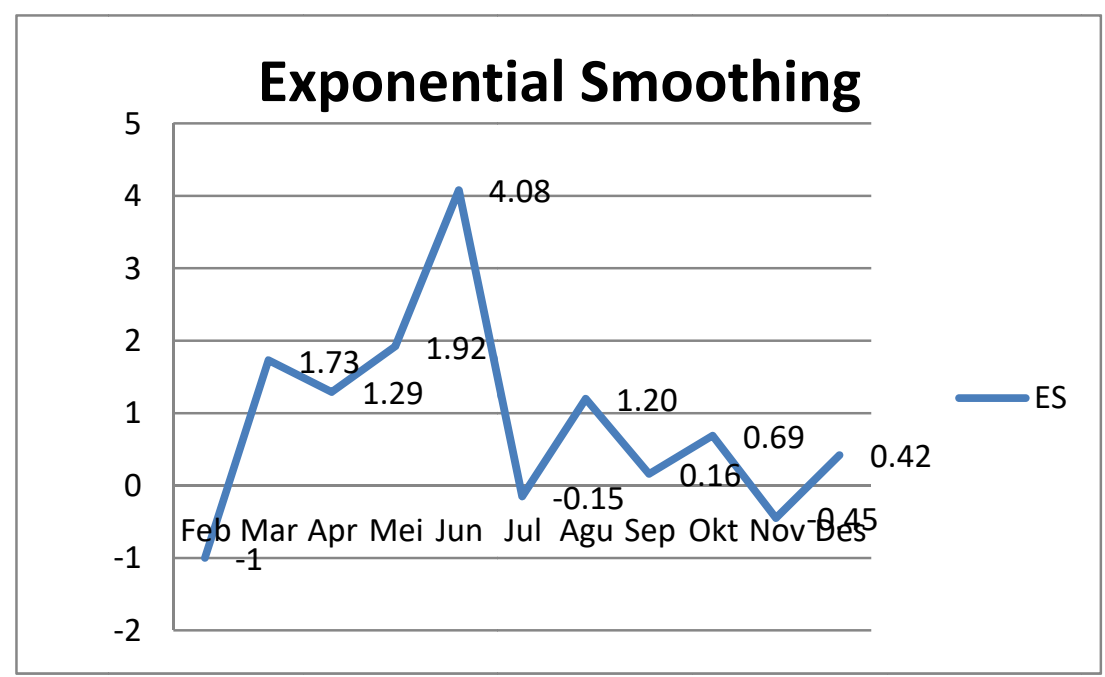

Figure 7. Tracking signal exponential smoothing method 
Table 4. Tracking signal using eksponential smoothing (ES) method

\begin{tabular}{|c|c|c|c|c|c|c|c|c|}
\hline $\begin{array}{l}\text { Period } \\
\text { N } \\
(1)\end{array}$ & $\begin{array}{l}\text { Demand } \\
\text { D } \\
\text { (2) }\end{array}$ & $\begin{array}{l}\text { Forecast } \\
\text { D't } \\
\text { (3) }\end{array}$ & $\begin{array}{l}\text { Error } \\
E=D-D ' t \\
\text { (4) }\end{array}$ & $\begin{array}{l}\text { RSFE } \\
(5) \quad= \\
\text { Cumulative } \\
\text { (4) }\end{array}$ & $\begin{array}{l}\text { Absolute } \\
\text { Error } \\
\text { (6) = } \\
\text { Absolute } \\
\text { (4) }\end{array}$ & $\begin{array}{l}\text { Cumulative } \\
\text { Absolute Error } \\
\text { (7) = } \\
\text { Cumulaitve (6) }\end{array}$ & $\begin{array}{l}\text { Cumulative } \\
\text { MAD } \\
(8)=(7) /(1)\end{array}$ & $\begin{array}{l}\text { Tracking } \\
\text { Signal } \\
(9)= \\
(5) /(8)\end{array}$ \\
\hline Jan & 2791625 & & & & & & & \\
\hline Feb & 2772230 & 2791625 & -19395 & -19395 & 19395 & 19395 & 19395 & -1 \\
\hline Mar & 3045500 & 2772424 & 273076.05 & 253681.05 & 273076 & 292471 & 146235.5 & 1.73 \\
\hline Apr & 2953190 & 3042769 & -89579.24 & 164101.81 & 89579 & 382050 & 127350.1 & 1.29 \\
\hline May & 2990440 & 2954086 & 36354.21 & 200456.02 & 36354 & 418404 & 104601.1 & 1.92 \\
\hline Jun & 3759400 & 2990076 & 769323.54 & 969779.56 & 769324 & 1187728 & 237545.6 & 4.08 \\
\hline Jul & 2726785 & 3751707 & -1024921.76 & -55142.20 & 1024922 & 2212650 & 368775.0 & -0.15 \\
\hline Agu & 3262080 & 2737034 & 525045.78 & 469903.58 & 525046 & 2737696 & 391099.4 & 1.20 \\
\hline Sep & 2851375 & 3256830 & -405454.54 & 64449.04 & 405455 & 3143150 & 392893.8 & 0.16 \\
\hline Oct & 3044645 & 2855430 & 189215.45 & 253664.49 & 189215 & 3332366 & 370262.8 & 0.69 \\
\hline Nov & 2620725 & 3042753 & -422027.85 & -168363.36 & 422028 & 3754393 & 375439.3 & -0.45 \\
\hline Dec & 2948390 & 2624945 & 323444.72 & 155081.37 & 323445 & 4077838 & 370712.6 & 0.42 \\
\hline
\end{tabular}

After calculation in the control chart can be seen from the graph exponential smoothing method, the results of this method exceeds the maximum limit of the highest Signal Tracking $\geq 4$ was in June that touched the figure of 4.08 , so this method is less accurate demand planning activities.

\section{Discussion}

Based on the forecasting method calculation in above, can be seen from the error value (error) which is the smallest, means resulted from the error value can be known about the reason the risk of errors occurring. Because being an forecaster person should have a mistake, and as much as a forecaster person have to known many mistakes but a forecaster cannot eliminate uncertainty, otherwise, only can reduce the uncertainty. Forecasting accuracy indicators are Mean Absolute Deviation (MAD), Mean Square Error (MSE) and Mean Absolute Percentage Error (MAPE). To know the control chart that is using Tracking Signal.

Table 5. Results of forecasting method

\begin{tabular}{lllll}
\hline No. & Forecasting Method & MAD & MSE & MAPE \\
\hline 1 & Moving Average & $284.598,5$ & $136.500 .264 .862,3$ & 0.09 \\
2 & Weight Moving Average & $262.496,6$ & $131.241 .939 .347,6$ & 0.09 \\
3 & Exponential Smoothing & $370.712,5$ & $225.928 .094 .308,6$ & 0.12 \\
\hline
\end{tabular}

After the comparison, there are 3 elements that can determine the accuracy of forecasting. Mean Absolute Percentage Error is a measure of the relative error. MAPE is usually more means than MAD because the percentage error MAPE stating the results of the actual demand against the forecast during a certain period which would provide information the percentage error is too high or too low. The above shows that the Moving Average and the Moving Average has a Weight smaller than MAPE Exponential Smoothing that is has the same value of 0.09 or $9 \%$. However, the Weight Moving Average has a size smaller than the MAD Moving Average, so the Weight Moving Average Method is a method which is best among the Moving Average and Exponential Smoothing and can be used as recommendations for PT TEMPO Group in conducting product demand forecasting.

After it is known which is the best method, and then subsequently do the determination of capacity planning the warehouse using the method of Simplex solver. Because the best method is already known then only the best method is shown in the map control. The Assessment undertaken include:

1). Priority $1=$ Total production of powder per shift of at least 2 (may be more, not less)

2). Priority 2 = Production of 1 talc required $800 \mathrm{gr}$ talc plus $500 \mathrm{gr}$ of mixed material 
3). Priority 3 = Production time is equal to (approximate) time available (should not be more, may be less)

In accordance with a linear equation then obtained the equation:

$\mathrm{C} 1=\mathrm{X} 1 \geq 2$

$\mathrm{C} 2=800 \mathrm{X} 1+500 \mathrm{X} 2=1$

$\mathrm{C} 3=20 \mathrm{X} 1+20 \mathrm{X} 2=360$

By using the simplex program solver, then obtained a production target per year as follows:

Table 6. Calculation of data

Target Cell (Max)

\begin{tabular}{rrrl}
\hline Cell & Name & Original Value & Final Value \\
\hline$\$ D \$ 10$ & Max X1 & 11217378,88 & 11217378,88 \\
\hline
\end{tabular}

Adjustable Cells

\begin{tabular}{cccc}
\hline Cell & Name & Original Value & Final Value \\
\hline \$D\$9 & Variable X1 & $-1,253333333$ & $-1,253333333$ \\
\hline \$E\$9 & Variable X2 & 2,053333333 & 2,053333333 \\
\hline
\end{tabular}

Constraints

\begin{tabular}{cccccc}
\hline Cell & Name & Cell Value & Formula & Status & Slack \\
\hline$\$ G \$ 6$ & $<=$ & 24 & $\$ \mathrm{G} \$ 6<=\$ \mathrm{H} \$ 6$ & Binding & 0 \\
$\$ \mathrm{G} \$ 5$ & $<=$ & 8 & $\$ \mathrm{G} \$ 5<=\$ \mathrm{H} \$ 5$ & Not Binding & 2 \\
$\$ \mathrm{G} \$ 7$ & $<=$ & 16 & $\$ \mathrm{G} \$ 7<=\$ \mathrm{H} \$ 7$ & Binding & 0 \\
\hline
\end{tabular}

\begin{tabular}{|c|c|c|c|c|c|c|c|}
\hline & & & Variabel & & & & \\
\hline & & & $\mathrm{X} 1$ & $\mathrm{X} 2$ & & & \\
\hline & & $\mathrm{C} 1$ & 5 & 0 & $<=$ & -6.26667 & 2 \\
\hline & $\bar{E}$ & $\mathrm{C} 2$ & 800 & 500 & $<=$ & 24 & 1 \\
\hline & $\tilde{\sigma}$ & $\mathrm{C} 3$ & 20 & 20 & $<=$ & 16 & 360 \\
\hline \multirow[t]{3}{*}{ Coef } & & F. Tujuan & 35766385 & 27294439 & & & \\
\hline & & Variable & -1.25333 & 2.053333 & & & \\
\hline & & Max & 11217379 & & & & \\
\hline
\end{tabular}

Based on the calculation, the maximum amount of production will be obtained by considering the forecasting of raw materials, production, material composition, and production time in 1 day by $11,217,379 \mathrm{pcs} /$ year, or 934,781 / month of finished powder products.

\section{Conclusion}

The method that obtained from Time Series forecasting method calculation, there are Moving Average which has error value from MAD 284.598,5 pcs \& MAPE 0.09, then Weight Moving Average method has MAD value from $262,496,6$ pcs \& MAPE equal to 0.09, and Exponential Smoothing method has the error value of MAD is $370.712,5$ pcs \& MAPE of 0.12 . Weight Moving Average method has MAPE value below $10 \%$, so it has a very good performance in demand forecasting. To know the average of absolute error the weight moving average method also has the smallest Mean Absolute Deviation (MAD) value so that the result of forecasting will be more accurate. Production planning using the selected time series method is the weight moving average method 
according to the calculation of maximum decision of 11,217,379 powder / year, or 934,781 powder / month.

\section{References}

Assauri, S. (2008). Manajemen Produksi dan Operasi. Jakarta: Lembaga Penerbit Fakultas Ekonomi UI. Hal.

Buffa, S. E., \& Rakesh, K. S. (2005). Manajemen Operasi \& Produksi Modern. Jakarta: Binarupa Aksara. Hal.

Endrawati, T., \& Siregar, M. T. (2018, March). Analysis of logistic distribution performance of good supply from PT. Mentari Trans Nusantara distribution center to branches using Smart PLS 3.0. In AIP Conference Proceedings (Vol. 1941, No. 1, p. 020007). AIP Publishing.

Gasperz, V. (2005). Planning and Inventory Control: berdasarkan pendekatan sistem terintegrasi MRP II dan JIT menuju Manufacturing 21. Jakarta: Gramedia Pustaka Utama.

Rini, K. P. (2014). Peramalan Permintaan Minuman Kesehatan Instan Jahe Menggunakan Jaringan Syaraf Tiruan dan Metode Time Series. Universitas Brawijaya Malang.

Sanny, L., Sarjono, H., \& Yiska, A. (2011). Penerapan Biaya Bahan Baku Log Kayu Menggunakan Metode Linier Programming Pada PT. Indoframe (Studi kasus: Metode Simplex dan Quantitative Management)

Sofyan, K. D. (2013). Perencanaan \& Pengendalian Produksi. Yogyakarta: Graha Ilmu. Hal.

Puar, Z. P., \& Siregar, M. T. (2017). Rancangan Sistem Elektronik Kanban Untuk Meningkatkan Efektivitas Produksi Just In Time. Jurnal Manajemen Industri dan Logistik, 1(1), 86-93. https://doi.org/10.30988/jmil. v1i1.11

Yuniastari, Ni Luh Ayu Kartika. (2011). Peramalan Permintaan Produk Perak Menggunakan Metode Simple Moving Average dan Exponential Smoothing. STIKOM Bali.

\section{Copyrights}

Copyright for this article is retained by the author(s), with first publication rights granted to the journal.

This is an open-access article distributed under the terms and conditions of the Creative Commons Attribution license (http://creativecommons.org/licenses/by/4.0/). 